\title{
PULEX IRRITANS.
}

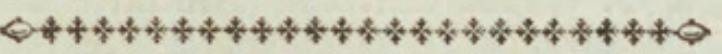

\section{CHARACTER GENERICUS.}

Pedes fex, faltatorii.

Oculi duo.

Antenna filiformes (feu potius moniliformes.)

Os roftro inflexo, fetaceo, aculeum recondente. Abdomen compreffum.

CHARACTER SPECIFICUS, \&C.

PULEX probofcide corpore breviore.

$$
\text { Lin. Syft. Nat. p. } 1021 .
$$

PULEX roftro corpore breviore,

$$
\text { Lin. Syft. Nat. Gmel. p. } 2923 .
$$

\section{PULEX COMMUNIS.}

Papilionaceis infectis ab ovo exortis fubeundas effe quafdam formæ mutationes antequam plene adoleverint, fere omnibus cognitum eft: paucis fortaffe, fimiliter voluiffe naturam in pulice. Ova pulicis minima et alba, inter pilos quadrupedum, plumas avium, et in variis ejufmodi locis a parente depofita, finito quafi hebdomade, in larvas excluduntur 
duntur parvulas, albidas, feu leviffime rubentes, agillimas, et variis modis fe contorquentes, fimul atque turbantur. Hæ cum ad plenam magnitudinem pervenerint, (circiter quintam fcilicet uncire partem) obvelantes fe operimento laxo, albo, et veluti goflipino expectant donec in chryfalidas mutentur; quod fit diebus circiter duodecim: et e chryfalide erumpit pulex jam perfectus. Quamvis moleftifimum fit hoc animalculum, negandum tamen non eft ineffe illi quandam formæ concinnitatem. Expeditifima eft nec inelegans corporis agilitas. Lorica, qua tegitur, nullis unquam fœdatur fordibus, fed nitet femper quafi polita. At tantum mufculofi roboris fpatio adeo exiguo contineri et terminari quis non miretur? cui forfan vix fimile invenitur in aliis omnibus animalibus; ne quidem in ipfis gryllis; poffe enim pulicem diftantiam fui ipfius corporis ducenties fuperantem uno faltu conficere fatis probavit nec exaggerata computatio, Socratem, quem de hac ipfa re finxit fe calculis torquentem, atro fale perfricuit Ariftophanes.

$$
\text { " } A \lambda \lambda \& \text { ฯ } \& \mu i \zeta_{5}, " \& c .
$$

$D i f c$. Sed fas non eft hæc cuiquam dicere nifi difcipulis.

Strepf. Mihi dic ergo audacter: ego enim ipfe

Venio in fcholam difcipulus.

D. Dicam, fed te oportct habere ifta pro myfteriis.

Modo interrogabat Chærephonta Socrates,

Pulex quot pedes fuos ipfius faltaret?

Cum enim momordiffet Chærephontis fupercilium, In caput Socratis inde faltavit.

S. Quo- 
S. Quomodo ergo iftud metiebatur? D. Scite admodum. Cera liquefacta, deinde pulice prehenfo, Immerfit in ceram pedes ejus :

Poft, refrigerato adnatæ funt crepidæ' Perficæ. His detraotis dimetiebatur locum.

S. O rex Jupiter, quanta fubtilitas mentis! AR: Nubes. aCI I. fc. 2.

Hujus quoque mordaces facetias tranftulit in poema fatiricum Butlerus noftras.

A capite ad calcem $\mathrm{fi}$ fit menfura, repertum eft Saltabit pulex quot fpatia ipfe fui :

Chære-que-phonteo tentamine, Socraticoque, Fruftra quæfitum tempore præterito.

Mira ineft pulicibus, ut et aliis multis infectis, revivifcendi facultas, vel ea paffis quæ vitæ funt inimiciffma. Narravit mihi ingeniofus quidam amicus quod fuo experimento confirmavit, revixiffe pulicem a calido aere, licet horas viginti et quatuor in aqua fuiflet immerfus. Infectis tamen nonnullis in claffe Coleoptera redintegrari folet vita vel longius fufpenfa. Defcriptionem infecti hujus belli et petulantis claudet epigramma lepidum quod legitur in carminibus quadragefimalibus Oxonii editis anno millefimo feptingentefimo vicefimo tertio.

Pulicis exigui tenues per colla catenas

Nexuit artifici pulchra Corinna manu.

Sic, inquit, pavo Junoni chara, palumbes

Sic Veneri; pulex tu mihi gratus eris.

Hic nova lafcivo teftatur gaudia faltu,

Et cadit in molles parvulus erro finus: 
Mox fuadente fiti, tanta eft folertia, fertur Qua fanguis rofeo femper in ore fedet. Credideris illic femper voluiffe morari, $\mathrm{Nec}$ Blandas unquam deftituiffe genas. Jam fecura potes nexas laxare catenas, Non opus artifici, pulchra Corinna, jugo. Dum licet hic pafci, licet hac in fede morari, Non tua eaptivum vincla, fed ipfa tenes. 

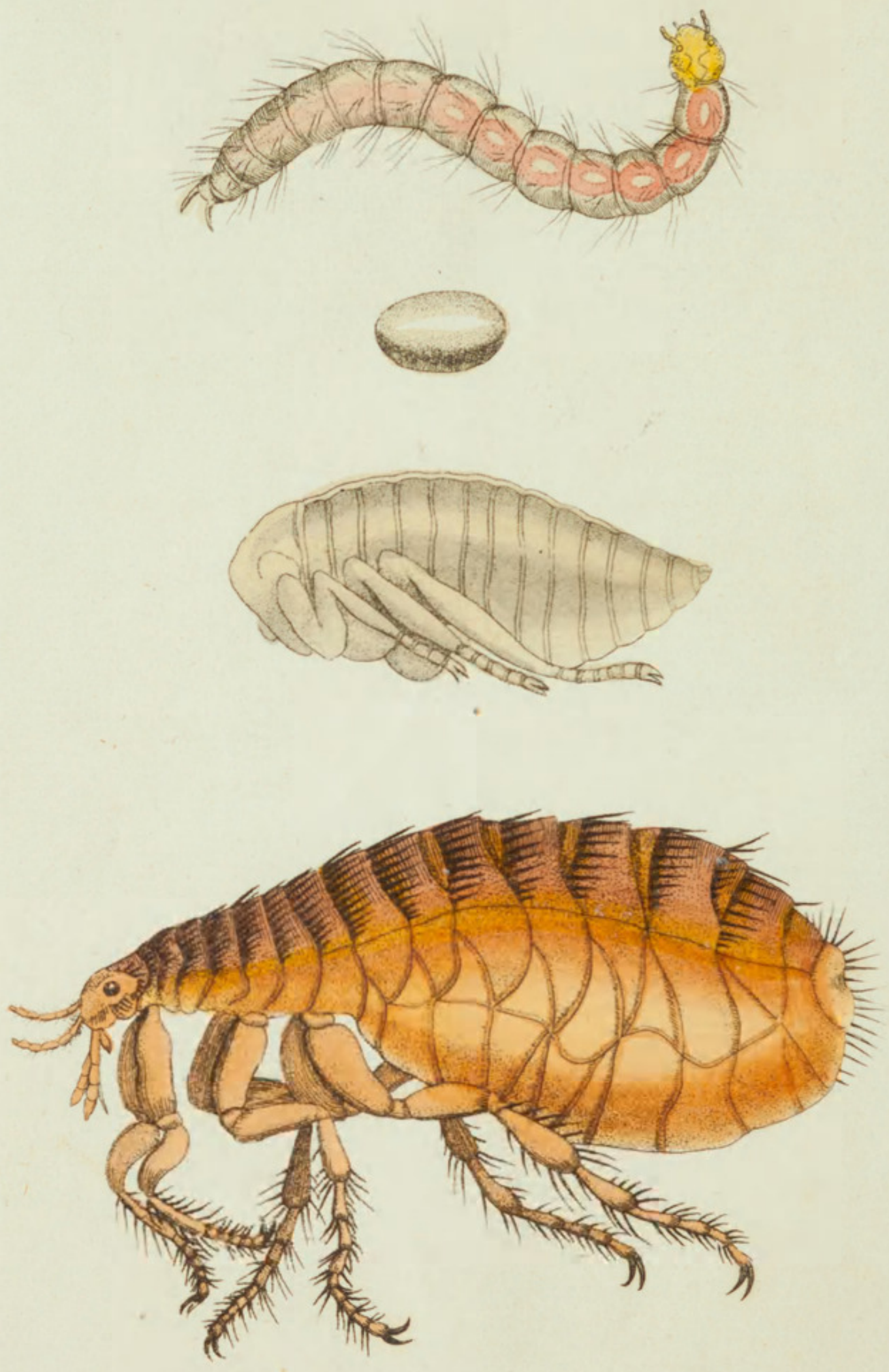

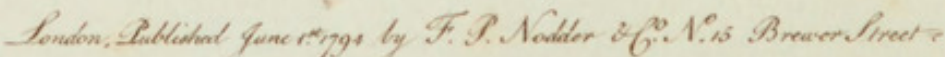




\section{F L E A.}

Q

GENERIC CHARACTER.

Feet fix, formed for leaping.

Eyes two.

Antennce filiform (or rather moniliform.)

Moutb confifting of an inflected fetaceous tube containing a tubular piercer.

Body compreffed.

\section{SPECIFIC CHARACTER, छ̋c.}

FLEA with probofcis fhorter than the body. THE COMMON FLEA.

The change of form in the papilionaceous infects during their progrefs from the egg to their complete ftate, is almoft univerfally known. But that a fimilar procefs takes place in the Flea, is perhaps by no means generally underftood.

The eggs of the Flea, which are very fmall, white, and of an oval furm, are depofited by the parent infect in various fituations favorable to their 
their evolution, viz. amongft the hair and on the fkins of quadrupeds, the feathers of birds, \&c. \&c. After the fpace of about a week they are hatched into fmall larvæ, which are of a whitifh colour, with a flight tinge of reddifh, and are extremely locomotive; and on being difturbed, throw themfelves into various fudden contorfions. When arrived at their full fize, they are about the fifth of an inch in length. At this period they prepare themfelves for their pupa or chryfalis ftate, by enclofing themfelves in a loofely fpun web or diffufed envelopement of a very foft, filky, or rather cottonlike appearance, and of a white colour. In this the larva changes into a chryfalis, out of which, in about the fpace of twelve days emerges the animal in its complete ftate.

Notwithftanding the inconveniences attending this little infect, and the general difapprobation which its frequency occafions, there is fomething pleafing in the appearance of the Flea. All its motions are elegant, and all its poftures indicate agility. The fhelly armour with which it is inveloped, is in a ftate of perpetual cleanlinefs; while the mufcular power which it is capable of exerting is fo extraordinary, as juftly to excite our wonder at fo much ftrength confined, and concentrated, as it were, in fo fmall a fpace. Perhaps of all animals the Flea poifeffes the greateft mufcular ftrength, and far exceeds in point of exertion all the infects of the locuft tribe; being able to fpring, on the moft moderate computation, to the diftance of at 
leaft two hundred times its own length. It is remarkable that Socrates was ridiculed for his pretended experiments on this very fubject, by the licentious pen of Ariftophanes.

Disciple.

That were not lawful to reveal to ftrangers.

Strepsiades.

Speak boldly then as to a fellow ftudent;

For therefore am I come.

Disc.

Then I will fpeak;

But fet it down amongft our myfteries.

It is a queftion put to Chærephon

By our great mafter Socrates to anfwer,

How many of his own lengths at one fpring

A flea can hop? for one by chance had fkipp'd

Straight from the brow of Chærephon to th' head

Of Socrates.

STr.

And how did then the fage

Contrive to meafure this?

\section{Disc.}

Moft dext'roufly.

He dipp'd the infect's feet in melted wax, Which hard'ning into flippers as it cool'd, By thefe computed he the queftion'd fpace.

\section{STR.}

O Jupiter, what fubtilty of thought!

Arist: Clouds. Act. 1. Scene 2.

The 
The celebrated Butler has alfo commemorated the fame circumftance in his poem of Hudibras, viz.

" How many feores a flea will jump

Of his own length, from head to rump;

Which Socrates and Chærephon

In vain affay'd fo long agon."

The Flea, like many other infects, is eminent for its powers of tevivefcence, and will frequently recover, after being placed in fituations highly unfavourable to animal life. I might here mention the experiment of an ingenious friend, who affures me that on immerging a flea in a vial of water, after being apparently drowned, and lying upwards of twenty-four hours, it has again revived on expofure to warm air. Some of the coleopterous infects are, however, capable of exhibiting far more ftriking examples of fufpended animation.

I thall conclude the defcription of this locomotive little infect by the following jeu d'efprit, relative to a flea which a lady is fuppofed to have kept in a ftate of captivity. The reader will find the original in that truly claffical publication the Carmina Quadragefimalia. Oxon. I 723.

Corinna, in a fportive vein,

A fav'rite Flea approves:

And faften'd by a golden chain

The little captive moves.

Not Juno view'd with more delight

Her peacock's train difplay'd:

Not Venus more her fav'rite dove

In changing plumes array'd. 
With confcious joy the infect fprings;

His foft confinement loves :

And finking on her fnowy breaft, In full luxuriance roves.

Then waking light from foft repofe, Attacks her rubied lips; And where the deepeft colour glows, The living vermil fips.

Loofe, fair Corinna, loofe his chain, Nor fear his flight away :

For how, thus tempted to remain, How fhould he wifh to ftray?

Permitted on thofe lips to feed, And flumber on that breaft, Thy charms, Corinna, not thy chains, Will fafteft bind the gueft. 


\section{$2 \mathrm{BHL}$ Biodiversity Heritage Library}

Shaw, George. 1794. "The Flea, Pulex irritanus [PI. 178]." The Naturalist's Miscellany 5(LIV), https://doi.org/10.5962/p.310757.

View This Item Online: https://www.biodiversitylibrary.org/item/276340

DOI: https://doi.org/10.5962/p.310757

Permalink: https://www.biodiversitylibrary.org/partpdf/310757

\section{Holding Institution}

Museums Victoria

\section{Sponsored by}

Atlas of Living Australia

\section{Copyright \& Reuse}

Copyright Status: Public domain. The BHL considers that this work is no longer under copyright protection.

This document was created from content at the Biodiversity Heritage Library, the world's largest open access digital library for biodiversity literature and archives. Visit BHL at https://www.biodiversitylibrary.org. 